Correction: Contributions and challenges of general

practitioners in China fighting against the novel

\title{
coronavirus crisis
}

Li DKT, Zhu S. Contributions and challenges of general practitioners in China fighting against the novel coronavirus crisis. Fam Med Com Health 2020;8:e000361

Since the online publication of the article, the authors noted some errors that have since been updated in the HTML and PDF versions of the article. The changes have been listed below:

1. Affiliations were conflated and listed with the incorrect geographical location

2. Authors should have been listed with equal contribution

3. The opening sentence has been changed from 'China was the first country where the novel coronavirus appeared.' to 'As the World Health Organisation calls for urgent, aggressive actions to combat COVID-19, China has been making positive contributions in the fight against the pandemic during the past few months.'

Open access This is an open access article distributed in accordance with the Creative Commons Attribution Non Commercial (CC BY-NC 4.0) license, which permits others to distribute, remix, adapt, build upon this work non-commercially, and license their derivative works on different terms, provided the original work is properly cited, appropriate credit is given, any changes made indicated, and the use is non-commercial. See: http://creativecommons.org/licenses/by-nc/4.0/.

(c) Author(s) (or their employer(s)) 2020. Re-use permitted under CC BY-NC. No commercial re-use. See rights and permissions. Published by BMJ.

Fam Med Com Health 2020;8:e00361corr1. doi:10.1136/fmch-2020-000361corr1

A) Check for updates 